\title{
Análise da ênfase prosódica em narrativas orais do ciclo de Lampião ${ }^{11}$
}

\author{
Gdalva da Conceição; Amanda Lassak; Renata Rosa; \\ Mayara de Sousa
}

\section{Introdução}

Picos de ênfase se caracterizam pela pronúncia de palavraschave com um tom mais alto do que o usual, pelo alongamento de vogais, aumento do volume de voz.

Os traços de desempenho prosódico (TDP) compõem um conjunto gradativo que dependerão do nível de envolvimento emocional do falante com o texto, a situação, a audiência (WENNERSTROM, 2001). A partir da conjunção desses fatores é possível mostrar os níveis de alteração alcançados pelos picos de ênfase, tomando como referência a medida de tom médio, apresentando as variações dos picos acima e abaixo dessa linha.

\section{Objetivo}

A proposta desse estudo é verificar, nas narrativas orais, as alterações dos picos de ênfase à medida em que o narrador vai se utilizando de recursos como traços de desempenho prosódico (TDP).

\footnotetext{
${ }^{11}$ CONGRESSO NACIONAL DE INICIAÇÃO CIENTíFICA - CONIC-SEMESP, 10. São Paulo, 2010.
} 


\section{Metodologia}

O material coletado para análise é composto de narrativas orais do ciclo dos cangaceiros nordestinos: Lampião e Antônio Silvino. A coleta foi realizada em um pequeno povoado rural do interior do Ceará, com gravador digital Zoom H4. São narrativas completas, mas de curta duração (menos de dois minutos). Depois fizemos a transcrição silábica das narrativas por meio do Speech Filling System (SFS). Esse material foi segmentado por meio da ExProsódia (FERREIRA NETTO, 2006; 2010) e esta gerou os dados necessários para análise.

\section{Apresentação e discussão de resultados}

Os resultados indicam que houve alteração dos dados levando em conta os intervalos mínimos de percepção (CONSON et alii; 2009).

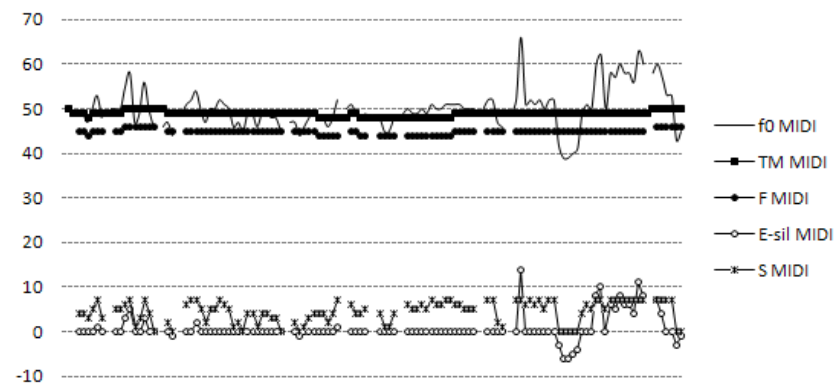

Figura 1. Gráfico da análise dos picos de ênfase

Essa variação caracterizou-se nos momentos em que o narrador faz uso dos recursos de traços de desempenho prosódico e avaliação conforme os critérios de conveniência que adotou para conseguir o efeito expressivo do relato. 


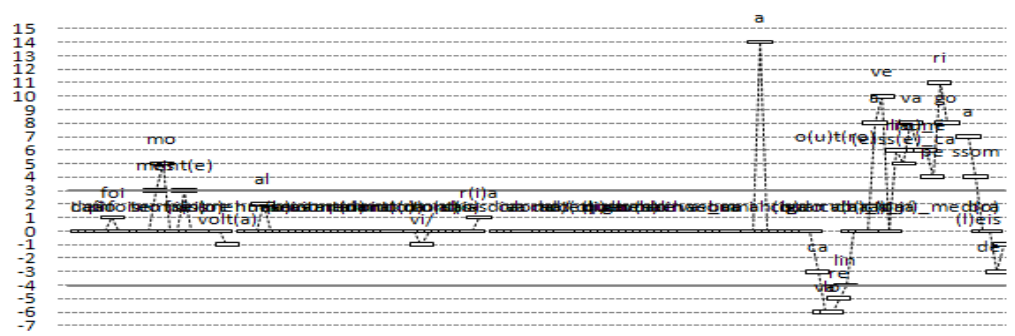

Figura 2. Gráfico da análise dos picos de ênfase da narrativa segmentada

Tanto na figura 4 quanto na figura 5 , podemos observar os momentos nos quais há picos de ênfase.

Segundo Wennerstrom (2001) a prosódia exagerada reflete as prioridades emocionais dos contadores de história. As formas prosódicas exageradas são associadas frequentemente com pontos de clímax de por meio de seu conteúdo léxicogramatical. 